\title{
MEMAKSIMALKAN BANDAR UDARA PULAU TERLUAR DALAM RANGKA MENDUKUNG PARIWISATA DAN PEREKONOMIAN (STUDI KASUS DI PULAU KARIMUN JAWA, JAWA TENGAH)
}

\author{
Ryan Firdiansyah Suryawan,SE.,MM.
}

\begin{abstract}
ABSTRAC
Karimun Java Island as one of the outermost islands with the potential of fishery field and tourism sector that enter into Jepara regency, Central Java. Seeing the potential of local governments need to give attention and reach out by providing convenience to the people of Karimun Jawa Island. The existence of seaports that can be sandari by veri boats quickly in a condition, and Dewadaru Airport that has not been maximized to be landed with bigger aircraft and more mauatan. The foundation is not sufficient and still needs to be developed for the future, so that later can be used as one of the place of loading and unloading of goods and as the descent of passengers or tourists who want to visit the island of Karimun Java
\end{abstract}

Keywords: Airport, and Regional Potential

\section{PENDAHULUAN}

Bandar Udara sebagai tempat mendarat berupa daratan landai yang bisa di darati oleh pesawat dalam melakukan kegiatan operasional menurunkan penumpang dan bongkar muat barang yang dibawa di dalam pesawat. Menurut Anex 14 dari ICAO (International Civil Aviation Organization) Bandar Udara adalah Area tertentu di daratan atau perairan (termasuk bangunan, instalasi dan peralatan) yang diperuntukkan baik secara keseluruhan atau sebagian untuk kedatangan, keberangkatan dan pergerakan pesawat. Dalam sistem bandar udara ada komponen- komponen bandar udara terdiri atas pengelolaan bandar udara, pengelolaan perusahaan angkutan udara, dan kebutuhan pengguna jasa angkutan udara, keluarannya berupa parameter utama untuk skala operasional yang mencakup kesesuaian antara pemenuhan permintaan angkutan penumpang dan barang, kapasitas angkutan udara, serta kapasitas bandar udara. Sarana dan prasarana Bandar Udara seperti sistem penerbangan negara, airport, jalur lalu lintas Udara, air traffic controller, fasilitas, dan sumber daya manusia.

Penyelenggaraan bandar udara memiliki keterkaitan dengan beberapa bidang antara lain pemerintahan pusat dan daerah, 
para pemegang konsesi, pemasok, polisi, pemadam api, ambulan dan layanan kesehatan, pengatur lalu-lintas udara, dan meteorologi. Selain hal itu, perusahaan angkutan udara juga memiliki (dalam sistem bandar udara) keterkaitan dengan berbagai bidang selain bandar udara antara lain pemasok bahan bakar, pemeliharaan pesawat udara, jasa boga udara, layanan sanitasi atau kebersihan, perusahaan angkutan udara atau penyedia jasa di darat lainnya. Dalam hal ini, pengguna jasa angkutan udara memiliki hubungan dengan pihak lain selain bandar udara dan perusahaan angkutan udara seperti pengantar dan penjemput penumpang serta perusahaan ekspedisi muatan udara dengan angkutan darat. Tanggung jawab regulator suatu negara adalah memastikan keselamatan penerbangan pada tingkat yang tertinggi pada unsur-unsur tersebut. Tugas dan tanggung jawab regulator memastikan derajat keselamatan yang paling tinggi dalam penerbangan (to assure the highest degree of safety in flight) dengan memberikan nasihat, bimbingan dan pengawasan (advice, guidance, oversight) dalam bidang keselamatan kepada industri penerbangan dalam wujud menerbitkan regulasi.

Sistem transportasi di suatu wilayah selalu dibangun dengan maksud membentuk suatu kesatuan dan perpindahan antar moda dalam suatu daerah. Oleh sebab itu, pembangunan dan pengembangan sistem transportasi wilayah direncanakan dan dibangun secara bertahap, berkelanjutan, komprehensif, dan terintegrasi dengan baik. Untuk menunjang pembangunan dan pengembangan ekonomi di daerah-daerah terpencil dan menghubungkan ke daerah yang sudah berkembang, pemerintah telah menerapkan kebijakan dalam menyediakan sarana angkutan yang menghubungkan daerah-daerah tersebut (Jinca \& Paulus, 2008). Seperti yang tertuang pada UU Nomor 1 Tahun 2009 dan Peraturan Menteri Perhubungan Nomor PM 9 Tahun 2016 bahwa:

"Dalam rangka menghubungkan daerah terpencil, daerah tertinggal, daerah yang belum terlayani oleh moda transportasi lain serta guna mendorong pertumbuhan dan pengembangan wilayah guna mewujudan stabilitas, pertahanan dan keamanan Negara, maka perlu diselenggarakan angkutan Udara perintis"

Kebijakan Pemerintah di bidang transportasi dalam mendukung program pengembangan daerah tertinggal dan wilayah perbatasan, sesuai misi Kementerian Perhubungan tahun 2010-2014 yaitu 
meningkatkan aksebilitas masyarakat terhadap pelayanan transportasi untuk mendukung pengembangan konektivitas antar wilayah.

Pulau Karimun Jawa yang termasuk dalam kategori daerah terluar yang memiliki sumber daya alam yang bisa menjadikan potensi di bidang pariwisata terutama dengan keindahan pantai-pantai yang memiliki pasir putih dan pulau-pulau kecil yang bisa dihuni dan belum tercemar, selain bidang pariwisata pulau Karimun Jawa juga memiliki potensi dalam bidang ekonomi perikanan, dimana hasil laut, dan budidaya ikan sebagai tumpuan masyarakat dalam mendapatkan penghasilan.

Kepulauan Karimunjawa termasuk dalam kecamatan Karimunjawa, Kabupaten Jepara, Jawa Tengah dan terdiri dari 29 pulau dengan luas wilayah 111.625 Ha yang terdiri dari 1.507,7 Ha daratan dan 110.117,3 $\mathrm{Ha}$ perairan. Desa Karimunjawa merupakan desa yang paling besar kepadatan penduduknya dibandingkan ketiga desa lainnya di Kecamatan Karimunjawa, yaitu Desa Kemujan, Desa Parang dan Desa Nyamuk. Penduduk Desa Karimunjawa sebagian besar memiliki mata pencaharian di sektor perikanan (Masyarakat Nelayan, Nelayan tangkap, Nelayan budidaya) dan pariwisata (Travel agent, Lokal Guide, Usaha penginapan, Usaha makan dan catering, usaha kapal wisata, usaha tempat wisata, Jasa transportasi, Sewa peralatan wisata).

Selain itu ada juga di sektor pertanian, pegawai negeri, buruh/swasta, pengrajin, pedagang dan peternak. Pekerjaan sebagai nelayan adalah pekerjaan yang sangat mendukung karena kondisi alam yang di kelilingi oleh lautan. Berdasarkan Statistik Daerah Kecamatan Karimunjawa Katalog No. 1101002.3320.120 (Badan Pusat Statistik Kabupaten Jepara Tahun 2016) jumlah penduduk terdata 9.242 jiwa yang terdiri dari penduduk laki-laki 4.660 jiwa, dan penduduk perempuan 4.582 jiwa, yang terbagi ke dalam 2.681 rumahtangga, sehingga rata-rata rumahtangga di kecamatan karimunjawa terdiri dari 3-4 jiwa. Penduduk terbanyak berada di desa karimunjawa sebanyak 4,672 jiwa jumlah penduduk kecamatan, sedangkan jumlah penduduk terkecil berada di desa Nyamuk yang berjumlah 55 jiwa.

Nelayan di Karimunjawa adalah nelayan tradisional dan mulai sekitar tahun 2005 menggunakan pancing sebagai alat tangkapnya. Sebelumnya nelayan menggunakan potasium, muroami dan kompressor untuk menangkap ikan. Hal ini membuat kondisi karang di Karimunjawa menjadi rusak sehingga jumlah ikan yang tersedia semakin sedikit. Jumlah penduduk 
yang bekerja sebagai petani tidak terlalu banyak karena kondisi alam yang kurang mendukung untuk usaha pertanian. Pengrajin yang ada di Desa Karimunjawa adalah pengrajin yang membuat keris, tongkat, stik komando dan tasbih yang sangat diminati oleh wisatawan sebagai kerajinan khas Karimunjawa.

Sarana dan prasarana yang ada dalam suatu wilayah sangat diperlukan untuk menunjang kegiatan pembangunan di wilayah tersebut. Sarana dan prasarana yang ada di Desa Karimunjawa diantaranya adalah sarana dan prasarana peribadatan, transportasi dan komunikasi, ekonomi, kesehatan dan pendidikan. Kelengkapan sarana dan prasarana ini sangat dibutuhkan dalam menunjang pengembangan pariwisata di Karimunjawa. Prasarana transportasi yang terdapat di Desa Karimunjawa terdiri dari jalan darat dan laut. Ketersediaan sarana ini untuk mendukung kegiatan perekonomian masyarakat.

\section{Sarana transportasi darat yang} digunakan adalah mobil dan sepeda motor, sepeda motor sangat dominan. Transportasi laut yang digunakan adalah perahu motor, kapal antar pulau, perahu tanpa motor dan perahu layar. Transportasi laut ini digunakan untuk mengangkut penduduk dan wisatawan dan mengangkut ikan hasil tangkapan nelayan ke Jepara. Jenis sarana dan prasarana komunikasi yang terdapat di Desa Karimunjawa terdiri dari telepon yang disediakan oleh Telkom Indonesia, providerprovider telekomunikasi swasta, Internet yang disediakan kepada aparatur pemerintahan berasal dari Telkom Indonesia (seperti jaringan telepon, internet usetv dan wifi.id).

Mobil penduduk yang disewakan dan sepeda motor yang digunakan oleh penduduk, juga digunakan untuk angkutan wisatawan karena wisatawan yang berkunjung tidak membawa kendaraan pribadi. Sejak adanya jaringan telekomunikasi, jumlah penduduk yang memiliki telepon pribadi semakin meningkat. Sejak itu juga, jumlah kunjungan wisatawan semakin meningkat. Kelancaran aktivitas perekonomian masyarakat dapat ditingkatkan dengan pengadaan sarana dan prasarana perekonomian karena ketersediaan sarana dan prasarana ini, masyarakat dengan lancar dapat melaksanakan aktivitasnya. Desa Karimunjawa memiliki sebuah Koprerasi Unit Desa Mina (KUD-Mina) yang diberi nama KUD Minoroso Sejati. KUD ini memberikan pelayanan terhadap berbagai kebutuhan masyarakat. Industri kerajinan yang ada saat ini menghasilkan produk seperti tongkat, keris dan tashbih, khas Karimunjawa. 
Kondisi wilayah yang dikelilingi lautan dan sulitnya transportasi membuat Kepulauan Karimunjawa sulit dijangkau oleh pelayanan kesehatan. Jumlah sarana kesehatan yang terdapat di Desa Karimunjawa masih kurang memadai dibandingkan jumlah penduduknya, yaitu 1 puskesmas dan 1 puskesmas pembantu, 1 apotik dan 10 posyandu. Air bersih yang digunakan berasal dari 2 mata air, salah satunya dari mata air dari Dukuh Legon Lele.

Listrik di Desa Karimunjawa diperoleh dari Pembangkit Listrik Tenaga Diesel dengan produksi 500 KVA dan tenaga surya. Penggunaan listrik sangat tergantung pada jumlah kehadiran wisatawan. Apabila terjadi peningkatan wisatawan, maka produksi listrik yang digunakan adalah $400 \mathrm{KVA}$ sedangkan jika jumlah wisatawan sangat sedikit maka listrik yang digunakan sekitar 200 KVA. Masyarakat hanya dapat memanfaatkan listrik selama 12 jam, yaitu dari jam 18.00-06.00 WIB. Setiap hotel memiliki diesel sendiri, namun kadang pihak hotel juga menggunakan PLTD desa sehingga mengurangi jatah penduduk. Sumber listrik lain yang digunakan adalah listrik desa (dulunya adalah milik Telkom) yang hanya bisa digunakan pada siang hari.
Obyek wisata Bakari Taman Nasional Laut Karimunjawa ini merupakan salah satu kawasan wisata yang unggul di tingkat regional dan tingkat International, Karimunjawa memiliki keindahan alam bawah laut yang alami dan sangat menakjubkan, dengan aneka jenis terumbu karang yang paling lengkap di dunia, laut dan ikan karang beraneka warna, hamparan pasir putih yang ada di setiap pulau dari 27 pulau menjadikan Karimunjawa layaknya surga bagi pengunjung wisatawan baik mancanegara maupun domestik.

Dengan melihat geografis dari salah satu pulau terluar yang masuk dalam Kabupaten Jepara, Jawa Tengah. Keadaan pulau-pulau terluar di Indonesia memang memnjadi perhatian dari pemerintah pusat terutama dalam menjangkau daerah dan ketersiapan transportasi yang terkoneksi dari transportasi laut dan transportasi udara. Adanya Pelabuhan yang terhubung dari daerah Pelabuhan Semarang, Pelabuhan Kartini dari Jepara dengan menggunakan kapal cepat untuk mencapai Pulau Karimun Jawa dan Bandar Udara Dewandaru yang berada di Pulau Karimunjawa ini yang disiapkan oleh pemerintah daerah dalam membantu akses dan memberikan kesempatan kepada masyarakat dalam hal menjual hasil perikanan (ikan 
kerapu, dan penangkaran hiu) rumput laut, hasil pertanian, hasil perkebunan, dan tentunya memanfaatkan sektor pariwisata yang bisa menjadikan obyek baru bagi wisatawan domestik maupun wisatawan mancanegara. Penyediaan layanan angkutan Udara secara efisien, dibutuhkan keseimbangan antara tingkat/kelas layanan, tarif angkutan Udara dan besar subsidi. Jika tarif yang ditetapkan terlalu tinggi maka berdampak pada pencegahan frekuensi lalu lintas Udara yang menyebabkan pemanfaatan sumber daya tidak optimal dan penurunan efisiensi biaya operasional. Sementara jika tarif terlalu rendah maka dan/atau kelas layanan terlalu tinggi, maka hal ini dapat meningkatkan besar permintaan terhadap layanan transportasi Udara, sehingga pemanfaatan sumber daya di perusahaan angkutan Udara menjadi tidak efisien.

Menurut H. K. Martono, (2011 : 178) Pengaturan Bandar Udara meliputi memberi pelayanan kepada pengguna jasa, merawat fasilitas yang ada, sehingga tetap terjaga. Pengembangan Bandar Udara sangat diperlukan dalam menigkatkan pelayanan kepada para pengguna jasa Bandar Udara yaitu,

a. Akan terjadinya penambahan biaya operasional bagi airlines; b. Mengakibatkan berkurangnya tingkat pelayanan jasa pengguna jasa Bandar Udara. Penerbangan dan Kebandarudaraan diselenggarakan.

Peraturan Menteri Perhubungan

Menurut K. Martono (2011 : 81), kegiatan pengusahaan Bandar Udara tersebut dapat berupa pelayanan jasa kebandarudaraan meliputi: pelayanan jasa pesawat udara, penumpang, barang dan pos yang kegunaannya untuk penyediaan atau pengembangan terhadap fasilitas pada kegiatan pelayanan pendaratan, lepas landas, manuver, parkir, dan penyimpanan pesawat udara, fasilitas terminal untuk pelayanan angkutan penumpang, kargo, dan pos, fasilitas elektronika, listrik, air, dan instalasi limbah buangan dan lahan untuk bangunan, lapangan, dan industri serta gedung atau bangunan yang berhubungan dengan kelancaran angkutan udara.

Yang terakhir dapat berupa pelayanan jasa terkait Bandar Udara meliputi kegiatan: jasa terkait untuk menunjang kegiatan pelayanan operasi pesawat udara di Bandar Udara di Bandar Udara yang terdiri atas penyediaan hanggar pesawat udara, perbengkelan pesawat udara, pergudangan, katering pesawat udara, pelayanan teknis penanganan pesawat udara di darat (ground 
handling), pelayanan penumpang dan bagasi, serta penanganan kargo dan pos. Jasa terkait untuk menunjang kegiatan pelayanan penumpang dan barang yang terdiri atas penyediaan penginapan atau hotel dan transit hotel, penyediaan toko dan restoran, penyimpanan kendaraan bermotor, pelayanan kesehatan, perbankan dan atau penukaran uang, transportasi darat. Jasa terkait untuk memberikan nilai tambah bagi pengusahaan Bandar Udara terdiri atas penyediaan tempat bermain dan rekreasi, penyediaan fasilitas perkantoran, penyediaan fasilitas olahraga, penyediaan fasilitas pendidikan dan pelatihan, penyediaan bahan bakar kendaraan bermotor dan periklanan.

Berdasarkan keputusan Direktur Jenderal Perhubungan Udara, terdapat berbagai jenis usaha penunjang kegiatan Bandar Udara Nomor SKEP/50/III/2007 tentang Usaha-usaha kegiatan penunjang Bandar Udara tersebut antara lain hotel reservation services, shops, restaurants, car parking, services cleaning, automatic check-in system services, refueling, general maintenance, porter, postal Utara services, telecommunication services, playground and recreation center, greeting services, travel agents, money exchange, ground transportation services, left baggage services, advertisement services, first class lounge, businness class lounge, VIP class lounge, hair dresser and beauty salon, agrobusiness services, nursery services, insurance agents, business center, vending machine dan lainlain.

Dilihat dari waktu tempuh perjalanan, transportasi udara relatif lebih unggul jika dibandingkan dengan transportasi darat dan laut. Dan akses menuju kepulauan Karimunjawa ini hanya dapat ditempuh dengan perjalanan udara dan laut saja. Mengingat perjalanan laut pada perairan jawa kerap dihambat oleh cuaca dan ombak tinggi sehingga jadwal perjalanan laut menjadi tidak menentu, maka perjalanan udara yang cenderung stabil merupakan alternatif yang baik dan efektif. Sebagai sebuah kepulauan, Karimunjawa telah memiliki sebuah bandara, yaitu bandara Dewadaru.

Bandara Dewadaru diklasifikasikan sebagai bandara perintis dengan kelas III yang dimaksudkan bahwa bandar udara ini dapat menampung lebih dari 100.000 orang pertahun. Namun fasilitas pada bandara ini kurang memadai, sedangkan prediksi permintaan rute penerbangan dari dan ke Karimuanjawa dipastikan akan mengalami peningkatan kedepannya. 
Transportasi perintis udara yang melayani rute Semarang- KarimunjawaSubaraya-Sumenep merupakan salah satu alternatif penerbangan menuju Bandara Dewadaru yang terletak di Pulau Kemujan, Kecamatan Karimunjawa, Kapubaten Jepara, Jawa Tengah. Perjalanan dengan waktu selama 30-40 menit menggunakan pesawat ATR atau Cessna dari Bandara Internasional Juanda-Bandara Dewadaru ini dijadwalkan untuk melayani satu kali frekuensi penerbangan Surabaya-Karimunjawa. Berikut rute penerbangan perintis Bandar Udara Dewadaru:

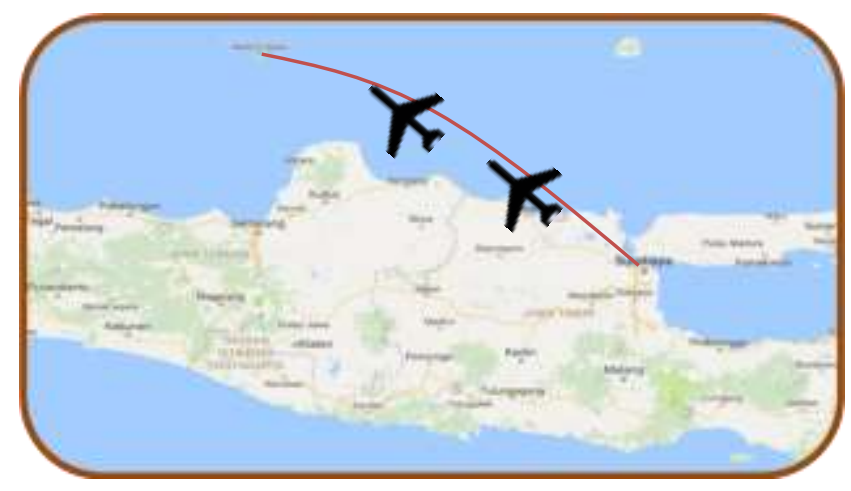

Gambar Rute Penerbangan

Penerbangan perintis memiliki peran untuk membuka daerah-daerah terisolir dan tentu saja menggairahkan bisnis pariwisata khususnya di daerah Karimunjawa. Berikut penetapan angkutan udara perintis dari dan ke Karimunjawa tahun 2016

1. Karimunjawa - Semarang: hari rabu dan jumat harga tiket Rp. 266.200,- (sudah tidak melayani)

2. Semarang - Karimunjawa: hari senin dan rabu harga tiket rp. 279.200,- (sudah tidak melayani)

3. Lama penerbangan 40 menit menggunakan pesawat DHC 6 Twin Otter.

4. Karimunjawa - Surabaya: hari senin dan rabu harga tiket Rp. 309.900,-

5. Surabaya - Karimunjawa: hari selasa dan kamis harga tiket rp. 379.900,(selasa) dan Rp. 379.900 (kamis)

6. Lama penerbangan 80 menit menggunakan pesawat DHC 6 Twin Otter.

\section{Memaksimalkan Bandar Udara di Pulau} Terluar

Kondisi Bandar Udara Dewadaru yang hanya bisa melayani penerbangan perintis yang ditunjuk dengan subsidi oleh pemerintah kepada PT. Airfast. Dengan hanya satu kali penerbangan dalam satu minggu maka untuk menjangkau dengan menggunakan pesawat jenis DHC-6 (Twin Otter) transportasi udara menuju Pulau Karimunjawa belum maksimal 
dan hanya di darati oleh pesawat dengan tipe kecil dengan Berdasarkan hasil wawancara dengan warga masyarakat, Kepala UPBU Bandar Udara Dewadaru mengenai adanya bandar udara Dewadaru yang ada di Pulau Karimunjawa hasilnya dalam bentuk tertulis dalam penelitian/jurnal ini ;

Peneliti : apa pekerjaan bapak-bapak dan mendapatkan penghasilan ?

Warga masyarakat : rata-rata pekerjaan masyarakat paling banyak adalah sebagai nelayan yang menangkap ikan, selain itu ada juga yang bertani tetapi tidak banyak, dan banyak masyarakat yang menjadikan rumah dengan sudah di renovasi terlebih dahulu untuk dijadikan sebagai penginapan.

Peneliti : jadi nelayan, petani dan wiraswasta, selama ini hasil dalam mendapatkan ikan menggunakan transportasi apa

Warga masyarakat : kebanyakan dari nelayan kami menggunakan kapal dalam menjual ikan ke daerah Jepara karena relatif lebih murah.

Peneliti : Adanya Bandar Udara di Pulau Karimunjawa kenapa apakah bapak mengetahui

Warga masyarakat : kami mengetahui adanya Bandar udara tersebut, kami tidak bisa secara terus menerus menggunakan pesawat untuk menjual hasil perikanan dikarenakan biaya yang mahal dan pesawat yang datang ke Bandar udara tidak rutin, hanya setiap kamis. Peneliti : jadi Bandar udara itu ada bukan digunakan oleh warga masyarakat

Warga masyarakat : sesekali menggunakan tetapi dikarenakan biaya yang relatif mahal maka kami warga lebih sering menggunakan kapal untuk mengirim ikan, membeli bahan dagangan atau untuk mendukung kehidupan dapur kami.

Penliti : kendala apa yang ada di daerah untuk mendukung warga dalam berkatifitas

Warga masyarakat : kadang-kadang harus mengantri bahan bakar minyak untuk kendaraan yang digunakan oleh warga seperti motor, mobil, dan truk-truk.

Peneliti : apakah sering terjadi keadaan seperti ini

Warga masyarakat : tidak, biasanya keterlambatan bahan bakar ada kendala dalam hal pengiriman ke Pulau

Dari hasil wawancara dengan warga masyarakat secara sepintas maka adanya Bandar udara di Pulau Karimunjawa belum bisa membantu secara maksimal untuk menopang perekonomian dikarenakan masih banyak warga masyarakat yang menggunakan kapal sebagai transportasi dengan menghubungkan daerah lain seperti ke 
Kabupaten Jepara ataupun ke daerah lain yang ada disekitar Pulau Karimunjawa seperti Pulau Madura.

Bandar udara Dewadaru dengan nama IATA KWB, ICAO WICM, memiliki klasifikasi Bandar udara ini memiliki ukuran landasan pacu 900 × 23 m, selain itu Bandar udara ini memiliki terminal yang tidak terlalu besar dengan penunjang keselamatan seperti PKP-PK seadanya, petugas Aviation Security dan SDM UPBU yang membantu dalam menjalankan kegiatan yang ada di Bandar udara berasal dan ditunjuk dari Direktorat Bandar Udara. Jadwal penerbangan yang ada untuk rute penerbangan perintis saat ini berasal dari PT. Airfastt dengan berangkat setiap hari Kamis dari Bandar Udara Juanda, Surabaya dengan menggunakan pesawat DHC 6 Twin Otter yang mengangkut 13 penumpang. Berikut adalah hasil wawancara dengan Kepala Bandar udara Dewadaru beserta jajaran yang ada di Bandar udara tersebut :

Peneliti : Bagaimana manfaat transportasi udara di Karimunjawa ?

Kepala UPBU :

Kepulauan Karimunjawa yang merupakan wilayah kepulauan sangat membutuhkan transportasi udara dikarenakan selama ini hanya mengandalkan transportasi laut yang sering mengalami kendala dikarenakan faktor cuaca dan tinggi gelombang sehingga transportasi udara akan menjadi solusi transportasi bagi masyarakat Kepulauan Karimunjawa. Tahun 2016 penerbangan $(1,6 \%$ dari kebutuhan masyarakat atau pergerakan masyarakat)

Dengan adanya subsidi manfaat bagi pengembangan dan melihat potensi (industri pariwisata dan industri lainnya);

- $\quad$ sangat diperlukan penerbangan perintis

- $\quad$ potensi rute semarang - karimun jawa, karimun jawa-surabaya

- $\quad$ Surabaya - karimun jawa (sumenep Surabaya (PP), Surabaya - bawean, karimun jawa - Surabaya (KPA)) beda cakupan.

- Wisatawan berasal dari Jogja, Semarang, dan Surabaya.

Peneliti : Bagaimana potensi pariwisata di Karimunjawa dengan adanya Bandar udara dan adanya penerbangan ?

Kepala UPBU : Karimunjawa ditetapkan sebagai 4 wisata unggulan Jawa Tengah bersama Borobudur, Sangiran dan Dieng sehingga dari tahun ke tahun selalu terjadi peningkatan kunjungan wisatawan yang berkunjung ke Karimunjawa.

Wisatawan sangat membutuhkan kepastian dalam hal transportasi dan waktu perjalanan 
sehingga transportasi udara sangat berpotensi untuk mendukung pariwisata di Karimunjawa dikarenakan transportasi laut sering mengalami kendala tidak dapat berlayar yang disebabkan oleh tinggi gelombang.

Peneliti : Menurut anda, faktor apa yang terpenting dalam transportasi udara selain keselamatan?

Kepala UPBU : Selain faktor keselamatan dan keamanan penerbangan hal yang tidak kalah pentingnya bagi para pengguna transportasi udara adalah faktor ketepatan waktu, ketepatan jadwal dan pelayanan yang baik serta nyaman bagi pengguna transportasi udara. Apakah fasilitas sudah memadai dalam menunjang keselamatan penerbangan ;

Hasil audit untuk fasilitas, temuan salah satunya ada tebing diujung yang menjadi obstacle alam (tanah bukit), lebar airstrip (90 M skrg 80 M penambahan 5 M kanan kiri), alat bantu belum punya (opsi perintis), fasilitas visual (Puppy dan RPIL), runway light. Untuk Komersil ATR 42 sdh cukup untuk PKP-PK, untuk ATR 72 belum bisa mencukupi.

Peneliti : Apa yang telah dilakukan Bandar Udara Dewadaru dalam meningkatkan pelayanan di Bandar Udara Dewadaru?

Kepala UPBU :
Dalam meningkatkan pelayanan angkutan udara di Bandara Dewadaru telah melakukan berbagai hal antara lain :

a. Study review masterplan yang dilaksanakan pada tahun 2017 untuk peningkatan kapasitas bandara agar dapat dioperasikan pesawat komersil sejenis ATR-72.

b. Pengadaan sarana keselamatan dan keamanan penerbangan antara lain : kendaraan PKP-PK tipe V, pemenuhan standar pagar Bandar udara, peningkatan catu daya dan lainlainnya.

c. Peningkatan kompetensi Sumber Daya Manusia untuk Avsec, PKP-PK, Teknik dan adminsitrasi kebandarudaraan.

d. Peningkatan sarana pengguna jasa bandar udara antara lain : rehabilitasi terminal penumpang dan pemasangan WIFI untuk memberikan kenyamanan bagi pengguna jasa bandar udara.

e. Bandara Dewadaru Karimunjawa sedang berkoordinasi dan mengupayakan untuk dapat dioperasikan pesawat komersil dengan pesawat ATR-42 (Kalstar). 
Peneliti : Bagaimana strategi yang dilakukan Bandara Dewadaru Karimunjawa untuk menarik pengunjung?

Kepala UPBU :

Bandara Dewadaru Karimunjawa bersama Pemkab Jepara dan Pemprov Jawa Tengah telah melakukan berbagai pemberitaan dan promosi guna untuk meningkatkan kunjungan wisata ke Karimunjawa. Berbagai event telah dilaksanakan oleh Pemkab Jepara dan Pemprov Jawa Tengah bersama dengan mitra swasta antara lain : Sail Karimunjawa, Let's Gowes Karimunjawa, Let's Go Fishing Karimunjawa, Festival Jazz, dll. Strategi menarik melalui tour and travel dengan menonjolkan industri pariwisata. (dari Pemda mempunyai perhatian yang besar dengan memasang Let's Gowes Karimunjawa)

Peneliti : Bagaimana animo masyarakat terkait menggunakan transportasi udara atau bandara tersebut, apakah mendapat respon positif terhadap keberadaan bandara?

Melihat data statistik selama 4 tahun terakhir: tahun 2013 : 979 penumpang; tahun 2014 : 1.066 penumpang; tahun $2015: 1.787$ penumpang dan tahun 2016 : 2.398 penumpang (terjadi waiting list reservasi tiket dan banyak penumpang yang tidak terlayani karena keterbatasan seat dan frekuensi penerbangan) memperhatikan data statistik tersebut maka animo masyarakat sangat mengharapkan transportasi udara sebagai salah satu sarana perjalanan menuju Kepulauan Karimunjawa

Peneliti : Apakah keberadaan bandara memberikan nilai ediet value (nilai tambah) kepada masyarakat, apa masyarakat makin sejahtera atau perekonomian masyarakat semakin meningkat?

\section{Kepala UPBU :}

Keberadaan Bandara Dewadaru sangat memberikan nilai tambah baik multi player effect maupun efek langsung bagi masyarakat Kepulauan Karimunjawa karena transportasi udara menjadi alternatif transportasi yang memberikan kepastian bagi masyarakat menuju Karimunjawa serta bagi investor yang sangat membutuhkan kepastian waktu dan kelancaran perjalanan menuju Karimunjawa Peneliti : Golongan kelas pengguna jasa angkutan udara perintis?

Kepala UPBU :

Kebijakan pengguna jasa angkutan udara perintis diprioritaskan bagi masyarakat Karimunjawa dan selanjutnya bagi wisatawan dalam negeri. Angkutan udara perintis tidak melayani wisatawan luar negeri. Efek adanya penerbangan perintis untuk masyarakat tidak ada. Efek bagi masyarakat secara global ada, contoh menolong orang hamil, emergenci 
untuk orang sakit, usaha tambak lobster----semua menggunakan transportasi udara (perintis kargo tidak tetapi secara program ada----tahun 2015 menggunakan caravan Susi Air)----pengaruh terhadap lobsternya waktu pengiriman dan resiko kematian.

Peneliti : Bagaimana Dampak Pertumbuhan ekonomi masyarakat dengan adanya Bandara Dewadaru Karimunjawa?

Kepala UPBU :

Meskipun Bandara Dewadaru baru memberikan kontribusi bagi transportasi menuju Karimunjawa sebesar 1,45 \% (Data 2016) namun Bandara Dewadaru telah memberikan dampak positif bagi pertumbuhan ekonomi masyarakat Karimunjawa hal tersebut terlihat dari animo dan harapan masyarakat Karimunjawa agar Bandara Dewadaru dikembangkan sehingga bisa melayani penerbangan komersil dan menjadi transportasi andalan yang memberikan kepastian terhadap waktu dan perjalanan bagi masyarakat Karimunjawa, wisatawan dan investor yang akan berkunjung ke Kepulauan Karimunjawa.

Peneliti : Berapa besar tarif untuk penerbangan perintis

Kepala UPBU

tarif kapal termahal Rp. 175 ribu dengan kapal feri cepat waktu dua jam, tariff Surabaya - karimun jawa Rp. 269.000,- (basic fare Rp. 246.000,- )...dilihat dari sisi waktu sudah murah. Utk tariff Charter rute semarang karimun jawa per satu jam Rp. 36.000.000,(utk penerbangan kalau ada kursi kosong utk penerbangan charter membayar Rp. 2,5 juta), waktu charter Mei - Oktober 2017

Pemkab Jepara masih memandang sebelah mata, sangirang, borobudur, dieng,

Dari hasil wawancara dengan Kepala Unit Pelaksana Bandar Udara Dewadaru, Karimunjawa, maka terlihat bahwa adanya Bandar udara yang sudah dibangun dan disediakan oleh Pemerintah daerah bisa digunakan untuk mendukung masyarakat sekitar dan mengundang kedatangan wisata untuk berkunjung ke Pulau Karimunjawa.

Potensi perekonomian yang ada di daerah bisa dimaksimalkan dengan memanfaatkan transportasi udara (penerbangan perintis) secara efisien dan efektif.

\section{KESIMPULAN}

Berdasarkan hasil wawancara serta, maka dapat disimpulkan ;

1. Sebaiknya penerbangan yang menuju Bandar udara Dewadaru ditambahkan dan bukan hanya satu maskapai.. 
2. Bandar udara Dewadaru bisa didarati dengan tipe pesawat yang lebih besar seperti ATR 42 sudah bisa mendarati Bandar udara Dewadaru.

3. Pembangunan infrastruktur dalam mendukung rutinintas dan bidang pariwisata seperti Hotel, Restoran dan sarana transportasi darat yang masih belum maksimal.

\section{DAFTAR PUSTAKA}

Arikunto, S. (2012). Prosedur Penelitian, Suatu Pendekatan Praktek. Jakarta: PT. Rineka Cipta.

Christina, N. (2013). Implementasi Kebijakan Pemerintah Daerah Tentang Subsidi Penerbangan Daerah Perbatasan Di Kabupaten Malinau (Studi pada Kecamatan Kayan Selatan). eJournal Pemerintahan Integratif, 2013, 1 (1), 65-74.

Creswell, J. W. (2014). Research Design: Qualitative and Quantitative Approach. California: Sage Publication.

Martono, H. (2011). Hukum Angkutan Udara. Jakarta: PT Raja Grafindo Persada.

Nasution, A. (2006). Menajemen Transportasi. Jakarta: Ghalia Indonesia.
Nazir, M. (2011). Metode Peneltian. Jakarta: Ghalia Indonesia.

Sudjana. (2006). Metode Statistika. Bandung: Penerbit Tarsito.

Sugiyono. (2015). Statistik Nonparametris Untuk Penelitian. Bandung: Penerbit Alfabeta.

Suyanto, B. (2015). Metode Penelitian Sosial: Bergabai Alternatif Pendekatan. Jakarta: Prenada Media.

Tangkilisan, Y. B. (2011). Kebijakan Penerbangan Perintis Di Indonesia: Latar Belakang, Tantangan Dan Kontribusi. Paradigma, Jurnal Kajian Budaya .

Undang-Undang Republik Indonesia nomor 1 Tahun 2009 tentang Penerbangan. Republik Indonesia.

H. K. Martono, Hukum Angkutan Udara, PT RajaGrafindo Persada, Jakarta , 2011, hlm 178.

Milton H. Spencer dan Orley M. Amos, Jr. dalam bukunya Contemporary Economics Edisi ke-8 halaman 464 dikutip oleh Rudi Handoko dan dan Pandu Patriadi 